Volume 2 Nomor 2, Desember 2019

E-ISSN : 2655-7347

\title{
Tanggungjawab Notaris/PPAT Dalam Pembuatan Akta Jual Beli Tanah Yang Tidak Memenuhi Asas Terang dan Tunai Dalam Kasus Putusan Majelis Pengawas Pusat Notaris Nomor: 04/B/MPPN/VIII/2016
}

Oleh :

\section{Charles Delon Tunas}

(Mahasiswa Program S1 Fakultas Hukum Universitas Tarumanagara)

Email: tinekke.hatulely@gmail.com

\section{Dr. Endang Pandamdari, S.H., C.N., M.H. \\ (Corresponding Author)}

(Dosen Fakultas Hukum Universitas Tarumanegara, Meraih Gelar Sarjana Hukum di Universitas Indonesia, Meraih Gelar Magister Hukum di Universitas Indonesia dan Meraih Gelar Doktor (Dr.) di Universitas Trisakti)

(Email: epandamdari@yahoo.com)

\begin{abstract}
Notary / PPAT is an official authorized to make a deed that is often sued for violations such as deeds drawn up and read in front of the buyer not in accordance with the agreement, but the Notary / PPAT continues the buying and selling process. If related to the case in this case, EJ makes AJB in his position as PPAT not as a Notary. The notary is personally responsible for carrying out his duties and positions in each deed making. Based on consideration of the decision of the Notary Central Board of Trustees, that EJ has acted inaccurately and does not safeguard the interests of parties related to legal actions so that EJ is considered to have violated Article 16 Paragraph (1) of the Law and the Article 54 paragraph (1) of the Act because the EJ does not keep a copy deed requested by the seller. MPPN's decision was in accordance with the provisions of UUJN, but the sanctions given by EJ were considered too light so that they did not have a deterrent effect. When acting as a PPAT, based on the provisions of Article 55 of Law No. 1/2006 jo PP No. 24 / 2016, PPAT is personally responsible for the implementation of the duties and positions in each deed making. The PPAT is faced with 4 (four) responsibilities, namely in terms of professional, administrative, civil and criminal ethics.
\end{abstract}

Keywords: Notary / PPAT responsibility, buying and selling land and buildings, light and cash

\section{PENDAHULUAN}

\section{A. Latar Belakang}

Salah satu pejabat yang memiliki kewenangan membuat dan menerbitkan akta otentik adalah Notaris/Pejabat Pembuat Akta Tanah (PPAT). Ada pula akta-akta yang dibuat oleh pejabat lain yang diberi kewenangan seperti mengurus akta nikah dan akta kelahiran yaitu pejabat pada Dinas Kependudukan dan Catatan Sipil. Namun demikian, pada penulisan ini lebih menekankan pada akta yang dibuat oleh Notaris/PPAT yang berkaitan dengan masalah jual beli tanah dan bangunan yang dilakukan secara KPR yang melibatkan pihak perbankan. 


\section{Jurnal Hukqum Adigamä}

Volume 2 Nomor 2, Desember 2019

E-ISSN : 2655-7347

Keotentikan akta yang dibuat oleh Notaris/PPAT dalam pembuatannya tetap berpedoman pada ketentuan peraturan perundang-undangan yang berlaku. Merujuk pada Pasal 1868 KUHPer, akta dapat dikatakan sebagai akta otentik apabila dibuat dalam bentuk sebagaimana yang telah diatur dalam ketentuan perundang-undangan dan dibuat dihadapan pihak atau pejabat yang berwenang sesuai dengan lokasi kedudukan akta itu dibuat. Selain itu, dalam UUJN menyaratkan adanya syarat materil dan syarat formil dalam pembuatan akta. Jika syarat tersebut tidak terpenuhi, maka tidak dapat disebut sebagai akta otentik, karena sifat keotentikannya sebuah akta menjadi hilang dan akan mengalami perubahan kekuatan pembuktiannya. ${ }^{1}$

Meskipun sama-sama berwenang membuat dan menerbitkan akta otentik, namun payung hukum kewenangan kedua pejabat tersebut berbeda. Kewenangan Notaris mengacu pada UUJN, ${ }^{2}$ sedangkan PPAT kewenangannya merujuk pada Peraturan Jabatan Pejabat Pembuat Akta Tanah yang tertuang dalam PP No. 24/2016 yang merupakan pengganti dari PP No. 37/1998. ${ }^{3}$

Kewenangan notaris secara keseluruhan dapat dilihat pada ketentuan Pasal 15 UUJN dan beberapa kewenangan tertentu juga diatur dalam peraturan perundangundangan yang lain. Adapun tugas dan kewenangan PPAT dapat dilihat pada Peraturan Pemerintah Nomor 24 Tahun 2016 tentang Peraturan Jabatan Pembuat Akta Tanah yang terurai dalam Pasal 2 Ayat (1) yang salah satunya menyatakan PPAT berwenang membuat akta jual beli terkait dengan pertanahan.

Pada umumnya, seringkali Notaris merangkap jabatan sebagai PPAT. Rangkap jabatan sebagai Notaris dan PPAT diperbolehkan dalam undang-undang, ${ }^{4}$ sepanjang di tempat kedudukan jabatan itu berada. Artinya tempat kedudukan notaris yang juga sebagai PPAT wajib mengikuti tempat kedudukan notaris.

\footnotetext{
${ }^{1}$ Vivin Pomantow, "Akibat Hukum Terhadap Akte Otentik Yang Cacat Formil Berdasarkan Pasal 1869 KUHPer”, Jurnal LexPrivatum. Vol.VI/No.7/Sept/2018, hal.90 (90-98).

2 Indonesia, Undang-Undang Nomor 2 Tahun 2014 tentang Perubahan Atas Undang-Undang Nomor 30 Tahun 2004 tentang Jabatan Notaris (UUJN); (LNRI Tahun 2014 No. 3; TLNRI No. 5491), Pasal 1 Ayat (1).

${ }^{3}$ Indonesia, Peraturan Pemerintah Nomor 37 Tahun 1998 tentang Peraturan Jabatan Pejabat Pembuat Akta Tanah (PP 37/1998), Pasal 1 Ayat (1), jo Peraturan Pemerintah Nomor 24 Tahun 2016 tentang Perubahan Atas Peraturan Pemerintah Nomor 37 Tahun 1998 tentang Peraturan Jabatan Pembuat Akta Tanah (PP 24/2016).

${ }^{4}$ Ibid, UUJN Pasal 17 huruf g jo PP No.24/2016, Pasal 7 Ayat (1).
} 


\section{Jurnal Huknm Adigamä}

Volume 2 Nomor 2, Desember 2019 E-ISSN : 2655-7347

Akta otentik yang dibuat Notaris/PPAT merupakan tanda bukti kepemilikan yang dapat menjamin kepastian hukum jika suatu saat nanti terjadi sengketa. Selain itu, akta otentik merupakan instrumen perlindungan hukum bagi pemiliknya. Dalam hal jual beli tanah dan bangunan, kini masyarakat sudah menyadari pentingnya legalitas dalam proses perbuatan-perbuatan hukum yang akan dilakukuan maupun sudah dilakukan dan kemudian dituangkannya dalam suatu dokumen dalam bentuk akta otentik. Kesadaran masyarakat membuat akta di hadapan pejabat yang berwenang menunjukkan masyarakat telah sadar bahwa untuk mendapatkan perlindungan dan kepastian terhadap objek yang dimilikinya dibutuhkan alat bukti berupa akta. Akta dapat dijadikan sebagai alat pembuktian yang dapat menentukan dengan jelas hak dan kewajiban setiap obyek hukum. Tujuan dibuatnya akta tidak lain agar menghindari atau meminimalisir terjadinya hubungan hukum yang bermasalah atau cacat dan dapat merugikan subjek hukum maupun masyarakat. ${ }^{5}$

Sejalan dengan perkembangan dalam dunia bisnis atau usaha banyak melibatkan para pihak dalam melakukan transaksi yang turut melibatkan notaris. Eksistensi notaris di era perkembangan bisnis saat ini memang sangat dibutuhkan oleh masyarakat dan pelaku bisnis lainnya. Oleh karena itu, notaris dituntut untuk bekerja secara professional dan penuh tanggungjawab dalam memberikan pelayanan publik dengan baik dan tanpa adanya keberpihakan sesuai dengan koridor standar pelayanan jabatan yang telah diatur dalam UUJN yaitu memberikan pelayanan hukum kepada masyarakat yang membutuhkan jasa notaris dengan baik dengan mengdepankan prinsip-prinrip kode etik jabatan notaris. ${ }^{6}$ Dengan demikian dapat dikatakan bahwa, jabatan sebagai Notaris timbul karena adanya faktor kebutuhan dari masyarakat di dalam mengatur pergaulan hidup sesama individu yang saling membutuhkan adanya suatu alat bukti perihal hubungan hukum yang bersifat keperdataan di antara mereka. ${ }^{7}$

Hubungan yang saling membutuhkan antara Notaris/PPAT dengan masyarakat dan negara jika berjalan sesuai dengan koridor hukum yang berlaku dapat

\footnotetext{
${ }^{5}$ Pengurus INI, Anke Dwi Saputro (ed), 100 Tahun INI, Jati Diri Notaris Indonesia: Dulu, Sekarang dan di Masa Mendatang, (Jakarta: Gramedia Pustaka, 2009), hal. 15.

${ }^{6}$ Habib Adjie, Hukum Notaris Indonesia Tafsir Tematik Terhadap UU No. 30 Tahun 2004 tentang Jabatan Notaris, (Bandung: Refika Aditama, 2015), hal. 10.

${ }^{7}$ Lumban Tobing, Peraturan Jabatan Notaris, Cetakan ke-4, (Jakarta:Erlangga, 1996), hal.30.
} 


\section{Jurnal HuGum Adigamä}

Volume 2 Nomor 2, Desember 2019

E-ISSN : 2655-7347

menciptakan hubungan yang positif sehingga diharapkan dapat memberikan ketertiban dan keamanan di tengah-tengah masyarakat. Notaris/PPAT dalam menjalankan tugas dan kewenangannya dalam pembuatan akta memang dituntut berlaku baik dan benar yang artinya akta yang dibuat itu memenuhi kehendak hukum dan permintaan pihak-pihak yang berkepentingan karena jabatannya sesuai dengan aturan hukum dan kehendak pihak yang berkepentingan dalam arti yang sebenarnya dan tidak mengada-ada atas akta yang dibuatnya serta harus menjelaskan atau membacakan isi akta sesuai maksud yang disepakati kedua belah pihak. ${ }^{8}$

Kaidah tersebut di atas memang sudah selayaknya dijalankan oleh Notaris/PPAT, karena jika diabaikan dapat merugikan Notaris/PPAT itu sendiri, organisas, negara bahkan masyarakat yang membutuhkan jasanya. Dalam tataran praktek di lapangan memang terkadang ditemui pelayanan Notaris/PPAT dalam memberikan jasa kepada masyarakat adakalanya tidak memuaskan karena berbagai hal yang mengakibatkan banyak ditemukan Notaris dilaporkan oleh klien ke lembaga kode etik profesi bahkan adapula yang dilaporkan secara perdata maupun pidana. Seperti yang diangkat pada penelitian ini, dalam Putusan Majelis Pengawas Notaris kasus Nomor: 04/B/MPPN/VIII/2016 telah ditemukan kasus Notaris yang dilaporkan oleh klien karena dinilai telah melakukan pelanggaran dalam menjalankan tugasnya karena dinilai telah bertindak tidak cermat, berpihak dan tidak menjaga pihak-pihak yang kepentingan terkait dengan dengan perbuatan hukum yang sedang dilaksanakan.

Dalam perkara tersebut, Notaris EJ yang merangkap jabatan sebagai PPAT dinilai bekerja tidak profesional karena keberpihakan terhadap salah satu pihak dalam pembayaran jual beli rumah secara KPR (Kredit Pemilikan Rumah) melalui Bank Yudha Bhakti (Bank BYB). Keberpihakan tersebut dapat dilihat dari tindakan Notaris EJ dalam membuat akta yang berhubungan dengan pertananahan, yaitu akta jual beli (AJB), tanah berikut bangunan milik $\mathrm{H}$ dan RR pasangan suami isteri yang dalam perkara ini selaku pihak yang menjual dan AA selaku pihak yang membeli. Notaris EJ dinilai telah bertindak tidak seksama serta tidak menjaga kepentingan pihak yang

\footnotetext{
${ }^{8}$ Ismantoro Dwi Yuwono, Memahami Berbagai Etika Profesi dan Pekerjaan, (Yogyakarta: Pustaka Yustisia, 2013), hal. 195.
} 


\section{Jurnal HuGum Adigamä}

Volume 2 Nomor 2, Desember 2019

E-ISSN : 2655-7347

berkaitan dalam perbuatan hukum yang tercantum dalam AJB tersebut, dalam hal ini tidak menjaga kepentingan pihak penjual.

Keberpihakan Notaris EJ juga dapat dilihat dalam proses KPR dimana Account Officer (AO) Bank BYB memiliki surat kuasa untuk memberikan sertipikat kepada pihak pembeli bukan kepada penjual selaku pemilik rumah. Selain itu, tidak menjaga kepentingan pihak penjual karena belum menerima hasil penjualan dan itupun harga yang tercantum dalam akta berbeda dengan harga yang disepakati sedangkan sertifikat telah beralih ke pihak pembeli. Harga yang disepakati yaitu Rp.500.000.000,- (limaratus juta rupiah), namun dalam akta yang dibuat dan dibacakan oleh Notaris EJ tertulis harga Rp.300,000.000,- (tigaratus juta rupiah). Notaris EJ juga tidak memberikan salinan minuta akta jual beli yang diminta oleh penjual dengan alasan tidak mengetahui keberadaan fotocopy minuta akta jual beli tersebut padahal telah menjadi kewajiban dan tanggung jawab notaris untuk menyimpannya dengan baik sebagai protokol notaris.

Apabila melihat ketentuan Pasal 16 Ayat (1) huruf (a) UUJN, notaris dalam melaksanakan tugas berkaitan pembuatan akta yang menjadi kewenangannya harus menjunjung tinggi nilai kejujuran, seksama dalam mengambil keputusan, dan mengedepankan sikap kemandirian dalam menjalankan tugas yang diemban dan tidak memihak kepada siapapun serta wajib menjaga kepentingan pihak yang terkait dalam perbuatan hukum. Notaris juga terikat dengan sumpah jabatan yang erat kaitannya dengan kode etik dan UUJN karena melalui sumpah atau janji jabatan seperti yang diatur dalam Pasal 4 UUJN, notaris berkewajiban untuk menjaga sikap dan tindakan dalam menjalankan tugas yang menjadi kewajibannya sesuai dengan ketentuan kode etik profesi, kehormatan, martabat dan tanggung-jawabnya sebagai notaris yang kedudukannya tidak memihak dan bersifat mandiri (independent). Notaris selaku pejabat umum wajib mempertahankan kenetralannya dan tidak diperkenankan mengabaikan salah satu pihak dengan cara membeda-bedakan antara pihak yang satu dengan pihak yang lain dengan alasan apapun baik alasan status sosial, ekonomi dan 


\section{Jurnal HuGum Adigamä}

Volume 2 Nomor 2, Desember 2019

E-ISSN : 2655-7347

lainnya dalam memberi jasa pelayanan kepada masyarakat yang menyangkut penerbitan akta otentik kepada salah satu dari mereka yang berkepentingan. ${ }^{9}$

Selain itu Notaris/PPAT dalam menjalankan tugasnya mengurus akta jual beli tanah dan bangunan harus memberikan pelayanan sebaik mungkin sesuai dengan profesinya. Memberikan informasi yang benar kepada para pihak yang dan membacakan akta dengan benar sesuai kesepakatan para pihak karena jika kondisi demikian terabaikan, maka salah satu pihak pasti akan ada yang dirugikan. Prinsip terang dan tunai dalam jual beli tanah dan bangunan harus pula diperhatikan oleh Notari/PPAT. Ketentuan Pasal 1457 KUHPerdata menegaskan bahwa jual beli adalah suatu perjanjian, dengan mana pihak yang satu mengikatkan dirinya untuk menyerahkan suatu kebendaan, dan pihak yang lain untuk membayar harga yang telah dijanjikan. Selanjutnya Pasal 1458 yang menyatakan bahwa jual beli itu di anggap telah terjadi antara kedua belah pihak, seketika setelah orang-orang ini mencapai sepakat tentang kebendaan tersebut dan harganya, meskipun kebendaan itu belum diserahkan maupun harganya belum dibayar.

Berkaitan dengan masalah jual beli tanah dan bangunan, maka berdasarkan Undang-Undang Nomor 5 Tahun 1960 tentang Peraturan Pokok-Pokok Agraria (UUPA), harus dilaksanakan secara terang dan tunai. Arti dari Sifat terang artinya disini karena wajib dilakukan dihadapan PPAT, pejabat yang ditunjuk khusus oleh pemerintah yang wilayah kerjanya sesuai dengan lokasi tanah yang akan dijual. Disebut tunai karena perbuatan penyerahan tanah dan pembayaran harga tanah dianggap terjadi bersamaan (simultan), yang dimana jual beli tersebut telah terpenuhi seketika tanah telah diserahkan. Jadi, pengertian dari terang dan tunai maksdunya proses penyerahan hak atas tanah dan bangunan harus dimuka pejabat yang berwenang, dalam hal ini PPAT, serta dibayar secara tunai dengan dibuktikan adanya Akta Jual Beli (AJB) sebagai dokumen adanya bukti peralihan hak atas tanah dari penguasaan pemilik selaku penjual yang kemudian berali kepada pembeli sebagai pemilik baru.

9 Sjaifurrachman dan Habib Adjie, Aspek Pertanggungjawaban Notaris dalam Pembuatan Akta, (Bandung: Mandar Maju, 2011), hal.65. 


\section{Jurnal Hukqum Adigamä}

Volume 2 Nomor 2, Desember 2019

E-ISSN : 2655-7347

Jual beli tanah dan bangunan dalam kasus ini, Notaris dan juga selaku PPAT pada saat pembacaan akta jual beli tidak dibayarkan secara tunai dan ada protes dari pihak pembeli terkait masalah harga yang tidak sesuai dengan kesepakatan awal, namun pihak Notaris/PPAT EJ tetap melanjutkan proses jual beli tersebut. Diabaikannya protes dari pihak penjual selaku pemilik tanah menunjukkan pelayanan Notaris/PPAT tidak mengindahkan keinginan penjual sesuai dengan kesepakatan awal dalam perjanjian sehingga salah satu pihak ada yang dirugikan atas jual beli tanah bangunan tersebut.

\section{B. Permasalahan}

Bagaimana tanggungjawab Notaris/PPAT dalam pembuatan akta jual beli tanah yang tidak memenuhi asas terang dan tunai dalam kasus Putusan Majelis Pengawas Pusat Notaris Nomor: 04/B/MPPN/VIII/2016?

\section{Metode Penelitian}

Pada penelitian ini, metode yang digunakan yaitu metode penelitian yuridis normatif atau dikenal juga dengan metode hukum normatif. Pendekatan yang digunakan lebih merujuk pada pendekatan peraturan perundang-undangan dan kasus dari putusan MPPN. Teknik pengumpulan data melalui library research atau kepustakaan dengan didukung data lapangan melalui wawancara. Data yang diperoleh melalui bahan hukum primer meliputi segala peraturan perundangan terkait, bahan sekunder meliputi buku, literatur, jurnal dan data internet dan bahan tersier berupa kamus hukum sebagai pendukungnya.

\section{ANALISIS}

Sebelum diuraikan lebih lanjut tentang tanggungjawab Notaris/PPAT dalam pembuatan atau penerbitan akta jual beli tanah dan bangunan yang tidak memenuhi asas terang dan tunai dalam perkara putusan Majelis Pengawas Pusat Notaris Nomor: 04/B/MPPN/VIII/2016, terlebih dahulu penulis akan menguaraikan mengenai keabsahan jual belinya. Sub pokok bahasan tersebut merupakan satu kesatuan dari permasalahan sehingga dengan mengetahui keabsahan perjanjian jual beli tanah dan 
Volume 2 Nomor 2, Desember 2019

E-ISSN : 2655-7347

bangunan terlebih dahulu setidaknya akan dapat memudahkan untuk menganalisis tanggungjawab Notaris/PPAT.

\section{A. Analisis Keabsahan Jual Beli Tanah dan Bangunan Yang Tidak Memenuhi}

\section{Unsur Terang dan Tunai}

Terang dan tunai dalam praktek jual beli tanah dan bangunan yang seringkali terjadi di masyarakat merupakan salah satu konsep yang dapat diartikan sebagai bentuk sifat keterbukaan dalam bertransaksi baik subjek maupun objek pemiliknya yang benar-benar jelas keberadannya serta tersedianya alat bukti otentik atas objek tanah seperti surat-surat kepemilikan berupa sertifikat maupun akta jual beli lain sebagai bukti kepemilikan. Hal ini sejalan dengan pendapat Notaris/PPAT Sri Rejeki Kasad, jual beli secara terang yang merujuk pada ketentuan Pasal 1868, 1870 dan 1873 KUHPer. ${ }^{10}$ Sementara tunai dapat diartikan sebagai bentuk pembayaran yang pada saat terjadinya transaksi ada bukti uang tunai saat itu juga seketika sesuai dengan harga kesepakatan kedua belah pihak.

Apabila dihubungkan dengan kasus yang telah di uraikan pada Bab III di atas, terkait dengan adanya Notaris/PPAT pada waktu membacakan AJB, Notaris/PPAT EJ telah diperingatkan atau diminta keterangan lebih lanjut oleh Hamid selaku penjual bahwa dirinya belum menerima uang sepeserpun dari apa yang telah di perjanjikan, sehingga seharusnya notaris tidak melanjutkan apa yang dirinya bacakan, tetapi justru notaris melanjutkan membacakan dan tetap membuatkan aktanya, dan para pihak di sini diminta untuk segera menandatangani akta tersebut. Menurut penulis akta jual beli tersebut tidak memenuhi kata sepakat dan tidak terpenuhinya asas terang dan tunai karena tidak dibayar saat seketika sesuai ketentuan bunyi akta pada saat dibacakan oleh Notaris/PPAT, meskipun dalam realitasnya kedua belah pihak menandatagani akta yang telah dibacakan yang seolah-olah penjual telah menerima pembayaran.

Akta yang dibacakan tidak sesuai dengan apa yang terjadi dan tidak sesuai dengan perjanjian yang sebenarnya, akta tersebut dapat diminta untuk dibatalkan akan tetapi dalam hal ini para pihak tetap menandatangi, sehingga inilah yang

${ }^{10}$ Peneliti, Wawancara, dengan Ibu Putri Rejeki Kasad, (Tangerang Selatan: Kantor Notaris dan PPAT Putri Rejeki Kasad, 30 Oktober 2019). 


\section{Jurnal Huknm Adigamä}

Volume 2 Nomor 2, Desember 2019

E-ISSN : 2655-7347

menjadi persoalan terkait dengan penandatanganan akta oleh para pihak dimana menurut pendapat penulis dalam hal ini adalah merupakan hal yang tidak wajar, apabila para pihak tersebut tidak setuju maka akta tersebut tidak dapat dilanjutkan, harus dibatalkan apabila tidak sesuai dengan kesepakatan para pihak, dimana para pihak dalam hal ini juga berhak protes terkait dengan akta tersebut, sehingga dalam hal ini patut di curigai terkait dengan adanya paksaan atau tekanan yang diberikan oleh Notaris EJ atau memanfaatkan ketidaktahuannya pihak penjual terkait dengan penandatangan akta tersebut.

Lazimnya, dalam praktek jual beli apapun bentuknya kedua belah pihak mendapatkan informasi yang benar dan transparan dari pihak notaris maupun pihak bank karena menyangkut hak pembeli yang harus mendapatkan kepastian atas transaksi jual beli tanah dan bangunan karena menyangkut harta benda yang dimilikinya. Informasi yang tidak transparan tersebut, patut dicurigai adanya dugaan persengkokolan atau itikad tidak baik yang dilakukan oleh Notaris EJ dengan pihak AO BYB dimana sekilas terlihat meyakinkan bahwa Notaris EJ dalam hal ini mengurus pembayaran rumah adalah AA dan AO BYB, sehingga Notaris EJ cenderung setuju dengan uang yang ada pada debitur ditahan terlebih dahulu menunggu pencairan dari sertifikat Jalan Sudirman. Apabila tidak ada pencairan maka transaksi tersebut dibatalkan demi alasan keamanan.

Mengenai hal ini, Hanafi Tanawijaya berbendapat bahwa akta itu harus sesuai dengan perjanjian/kesepakatan yang tertuang dalam Pasal 1320 KUHPer perihal keabsahan suatu perjanjian yang harus terpenuhinya syarat-syarat sahnya perjanjian yang merujuk pada empat syarat, yaitu:

1. Kedua belah pihak bersepakat untuk mengikatkan dirinya dalam sebuah perjanjian yang disepakati bersama.

2. Baik penjual maupun pembeli sudah pantas melakukan perbuatan hukum atau yang sering dikenal kecakapan kedua belah pohak untuk membuat suatu perikatan.

3. Suatu hal tertentu dalam perjanjian lebih kepada objek perjanjian yang berarti adanya wujud objek benda yang diperjanjikan. 
4. Suatu sebab yang halal lebih menekankan pada perjanjian yang legal dan tidak ada umpatan kecacatan dari perjanjian yang disepakati bersama.

Apabila salah satu dari keempat syarat tersebut tidak terpenuhi, maka kekuatan akta tersebut tidak memiliki kekuatan pembuktian yang sempurna karena adanya cacat pada akta tersebut. ${ }^{11}$

Berdasarkan ketentuan syarat sahnya perjanjian tersebut di atas, maka apabila dihubungkan dengan tindakan Notaris/PPAT EJ jelas bertentangan dengan ketentuan Pasal 1320 KUHPer yakni adanya pertentangan kesepakatan para pihak dimana para pihak seolah dipaksa oleh Notaris EJ untuk menandatangani AJB, yang berisikan kejanggalan-kejanggalan seperti ketidaksesuaian nominal harga dengan kesepakatan. Dalam kasus ini sebaiknya para pihak melakukan perundingan terhadap notaris mengenai keinginanya, tetapi dalam hal ini notaris tidak memberikan kesempatan bagi para pihak untuk menjelaskan keinginan mereka dan notaris tersebut dengan segera membuatkan akta jual beli, dan para pihak sekali lagi seolah dipaksa untuk menandatangi akta tersebut sesuai dengan keinginan Notaris EJ. Berdasarkan ketentuan Pasal 1320 KUHPer, perjanjian tersebut dianggap tidak sah secara hukum karena tidak terpenuhinya kata sepakat mengenai harga jual yang tidak sesuai kesepakatan kedua belah pihak.

Apabila ditinjau berdasarkan ketentuan Pasal 1338 KUHPer yang secara garis besarnya menyatakan semua perjanjian yang dibuat secara sah berdasarkan kesepakatan kedua belah pihak menjadi pengikat bagi kedua belah pihak sebagai undang-undang yang berlaku bagi kedua pihak tersebut. Dengan mengikatkan diri melalui kesepakatan yang dibuat, maka perjanjian yang telah dibuat tidak dapat ditarik kembali selain dengan sepakat kedua belah pihak, atau karena alasanalasan yang oleh undang-undang dinyatakan cukup untuk itu. Suatu perjanjian harus dilaksanakan dengan itikad baik, akan tetapi penulis menilai terdapat itikad yang tidak baik dari Notaris/PPAT EJ dan kesepakatan perjanjian para pihak yang tidak sesuai dengan yang seharusnya di perjanjikan. Tindakan tersebut jelas telah

${ }^{11}$ Peneliti, Wawancara, dengan Bapak Hanafi Tanawijaya, selaku dosen FH Untar, (Jakarta: Fakultas Hukum Gedung Blok M Lantai 4, 14 November 2019). 


\section{Jurnal Huknm Adigamä}

Volume 2 Nomor 2, Desember 2019

E-ISSN : 2655-7347

bertentangan dengan Pasal 1320 dan Pasal 1338 KUHPer, meskipun perjanjian tersebut tetap dituangkan dalam AJB dan Hamid tetap menandatangani akta yang tidak sesuai dengan kenyataannya. Hal tersebut seharusnya tidak dapat terjadi apabila Notaris EJ memiliki itikad baik, akan tetapi Notaris EJ bersikukuh untuk tetap membuat AJB dan terkesan memaksa untuk menandatangani AJB tersebut, sehingga para pihak menandatangani. Kemudian Notaris EJ tidak berhasil ditemui sementara para pihak dalam hal ini ingin menanyakan perihal Salinan AJB atas nama Hamid menjadi Ari Arjana dan perihal pembayaran seperti apa yang dilampirkan dalam Salinan AJB tersebut. Pegawai Notaris EJ berdalil bahwa EJ tidak mempunyai salinan AJB karena sudah dikirimkan kepada Bank BYB, lalu usaha para pihak hanya diberikan catatan ekspedisi surat-surat Ari Arjana ke bank BYB yang dengan jelas disini menurut pendapat penulis, Notaris/PPAT EJ telah melanggar Pasal 16 huruf b UUJN karena pada saat dimintakan copyan minuta akta oleh Hamid tidak dapat memberikan minuta akta yang merupakan kewajiban notaris untuk menyimpannya sebagai bagian dari protokol notaris.

Dengan tidak menyimpan minuta akta tersebut, maka tindakan Notaris/PPAT EJ tidak sesuai dengan aturan perundang-undangan yang berlaku dimana dirinya tidak bertanggungjawab dalam hal menyimpan akta, dikarenakan akta yang berpindah-pindah tempat dan tidak sesuai dengan ketentuan dimana notaris haruslah menyimpan akta sesuai dengan protokol notaris.

MPD Kota Bandung telah melakukan pemeriksaan sehingga terdapat 3 (tiga) fakta hukum, yang menurut penulis secara jelas terlihat kelalaian dari seorang Notaris EJ dengan perjanjian penjualan yang telah disepakati sebelumnya antara lain sebagai berikut:

a. Harga tercantum dalam akta berbeda dengan kesepakatan para pihak, seharusnya harga yang disepakati sebesar Rp.500.000.000,00 (limaratus juta rupiah), tetapi di dalam akta tercantum harga penjualan sebesar $300.000 .000,00$

b. Notaris lalai pada waktu proses balik nama untuk menginformasikan kepada pelapor tentang pembayaran objek jual beli, karena pembayaran tidak bisa dikirmkan langsung kepada Penjual akibat ketentuan dari Bank BYB bahwa 
yang mengajukan KPR adalah AA jadi pencairan harus melalui AA, kemudian dalam hal ini para pihak yang bersangkutan menanyakan Salinan AJB atas nama Hamid menjadi AA, di sini terjadi permasalahan hukum terkait dengan proses balik nama yang tidak sesuai dengan kesepakatan.

c. Sertifkat telah beralih ke AA tetapi objek jual beli masih berada di Hamid dan RR hal ini seharusnya tidak terjadi apabila proses pembayaran sesuai dengan yang disepakati sebelumnya yakni pembayaran ke Hamid.

Berdasarkan fakta hukum di atas, MPD berpendapat adanya kelalaian Notaris EJ yang menyebabkan kerugian pihak penjual yakni Hamid dan RR. Seperti yang diketahui, Pasal 70 UUJN huruf g, fungsi dari MPD menerima laporan dari masyarakat mengenai adanya dugaan pelanggaran kode etik notaris dan UUJN. MPD memiliki kewajiban yang antara lain kewajibannya memeriksa dugaan pelanggaran yang dilakukan dan menyampaikan hasil investigasi tesebut kepada MPW.

Oleh karena itu atas kelalaian yang dilakukan oleh Notaris EJ, MPD berpendapat bahwa dengan adanya fakta-fakta hukum tersebut maka patut diduga telah terjadi kelalaian yang dilakukan Notaris EJ, kemudian MPW berdasarkan kewenangannya menurut pasal 73 UUJN mengusulkan ke MPP agar Notaris EJ dijatuhkan sanksi pemberhentian sementaran selama 3 (tiga) bulan.

Pada tanggal 5 Maret 2016 notaris EJ melakukan banding terhadap putusan MPW, dengan memori banding antara lain:

1. Pertanggungjawaban atas kelalaianya merupakan wewenangnya sebagai seorang PPAT atas akta PPAT;

2. Terkait dengan pembayaran yang belum diterima penjual, Notaris EJ mengakui lalai untuk menginformasikan kepada Hamid dan RR tentang pembayaran objek jual beli.

3. EJ menyatakan tidak ada saksi dalam AJB

4. Hamid dan RR selaku penjual sudah 3 (tiga) kali datang ke Notaris EJ untuk meminta fotocopy atau Salinan AJB

Sebelum EJ menjelaskan mengenai keberatannya terlebih dahulu ia menjelaskan kronologis sebagai berikut: 
a. EJ menjelaskan bahwa Oktober 2011, pihak legal Bank Yudha Bhakti menghubungi EJ terkait rencana jual beli atas sebidang tanah, bangunan, dan tanaman serta segala sesuatu di atas tanah yg terletak di J1, Golf Barat D XII No. 12A (sekarang diubah menjadi No. 41, selanjutnya disebut tanah) atas nama Hamid dengan SHM Nomor 4485/Sukamiskin Gambar Situasi tanggal 23 Juli 1987, Nomor 5544/1987 seluas 176 M2;

b. EJ menjelaskan terkait dengan keterangan yang diberikan oleh legal dan AO BYB bahwa tanah tersebut akan dijual atau dibeli oleh AA melalui KPR Bank BYB;

c. EJ meminta kelengkapan berkas-berkas terkait tanah yang akan dijual dikarenakan adanya rencana jual beli;

d. Setelah berkas lengkap, EJ mengecek keaslian SHM kepada Kantor BPN Bandung;

e. Pada tanggal 3 Januari 2012, selanjutnya EJ mengecek ulang ke Dispenda Kota Bandung untuk verifikasi objek pembayaran;

f. EJ melanjutkan dengan pembayaran pajak-pajak jual beli yaitu pembayaran PPH dan pembayaran BPHTB;

g. Setelah AJB selesai dibuat, BYB menginformasikan para pihak umtuk menandatangani akta tersebut pada tanggal 18 Januari di Kantor BYB;

h. Sebelum AJB tersebut ditandatangani, EJ terlebih dahulu membcakan dihadapan para pihak yang hadir;

i. EJ telah melakukan konfirmasi terkait dengan keberatan dan ketidakjelasan dengan AJB;

j. Pada saat membacakan AJB tersebut, maka pihak yang akan mebayar adalah Bank BYB yang diwakili oleh OA BYB;

k. EJ sudah melakukan konfitrmasi terkait pencairan fasilitas KPR;

1. EJ telah melakukan proses peralihan hal/balik nama;

m. Kemudian EJ menyerahkan SHM berserta dokumen dokumen lainnya kepada Bank BYB.

Berdasarkan kronologis permasalahan yang dialami oleh EJ, ia berdalil bahwa: 
a. Terdapat identitas penjual dan pembeli yakni penjualnya adalah Hamid, sedangkan penjualnya adalah AA.

b. Bahwa benar ada permohonan pembuatan AJB oleh AO BYB yang mana objek jual belinya adalah sebidang tanah SHM No. 4485/Sukamiskin atas nama Hamid sebesar 300.000.000,00 (tiga ratus juta rupiah

Berdasarkan uraian di atas, penulis berpendapat bahwa ketidaksesuaian nominal harga yang disepakati para pihak sebelumnya dilakukan dengan tujuan untuk menghindari pembayaran pajak yang lebih besar, dalam praktiknya hal tersebut memang kerap kali dilakukan.

Menurut EJ dalam hal ini dirinya menyatakan dalam dalilnya bahwa dirinya sudah menyerahkan SHM berserta berkas-berkas lainnya kepada Bank BYB akan tetapi penulis dalam hal melihat bahwa adanya pertentangan pendapat dimana dalam hal ini adanya pendapat bahwa penjual telah berusaha mencari Salinan copy AJB ke berbagai Bank dan tidak mendapatkan apa yang dirinya cari bahkan menurut pegawai notaris tersebut tidak memiliki copy atau Salinan dari AJB tersebut karena sudah dikirmkan kepada Bank BYB.

Menurut penulis dalam hal ini pendapat dari Notaris EJ tidak dapat dipertanggungjawabkan dikarenakan merupakan suatu kebohongan untuk menghindari sanksi yang akan dijatuhkan kepada dirinya sebab tidak mungkin seorang pegawai notaris mengatakan bahwa Salinan atau copy tersebut tidak ada di tempat Notaris EJ berada, dan tidaklah mungkin seorang pegawai notaris menyembunyikan akta tersebut, dan diyakini dalam hal ini Notaris EJ menyembunyikan keberadaan yang sebenarnya sebab penjual telah mengecek ke segala tempat termasuk ke Bank BYB dan Bank Maspion dan ke berbagai bank lainnya.

Notaris EJ menyatakan bahwa dirinya telah memberikan tanda terima sesuai dengan tanda terima, akan tetapi pihak penjual dalam hal ini menyatakan bahwa dirinya tidak menerima apapun juga dari pihak notaris maka dalam hal ini yang menjadi permasalahan adalah terkait dengan kebenaran dari apa yang di sampaikan oleh penjual dan notaris tersebut berbeda. 
Di tingkat MPP, Notaris EJ dinyatakan bersalah karena telah terbukti melanggar Pasal 16 Ayat (1) huruf (a) UUJN karena lalai dalam melaksanakan tugas dan tanggungjawabnya yang mengakibatkan kerugian pihak penjual. Putusan MPP membatalkan Putusan MPW sehingga sanksi yang diterima Notaris EJ hanya berupa teguran tertulis.

Berdasarkan Putusan MPP tersebut, Notaris EJ yang dijatuhkan sanksi teguran tertulis yang dirasa kurang tegas karena Notaris EJ telah melakukan banyak pelanggaran-pelanggaran yang seharusnya hukuman yang diberikan pemberhentian sementara agar memiliki efek jera sehingga notaris dalam menjalankan profesinya menjunjung tinggi kode etik dan UUJN serta menganut prinsip kehati-hatian.

Berdasarkan penjelasan uraian di atas, maka dapat diketahui bahwa perjanjian jual beli dapat dikatakan sah apabila memenuhi syarat-syarat keabsahan perjanjian selain ditentukan dalam ketentuan Pasal 1320 KUHPerdata, juga diatur secara khusus dalam peraturan perundang-undangan yang terkait. Apabila suatu perjanjian yang dibuat dengan cara melanggar hukum, maka konsekuensi hukumnya adalah perjanjian tersebut menjadi batal dan salah satu alasan yang menyebabkan batal demi hukumnya perjanjian apabila perjanjian itu dibuat dengan paksaan, kekhilafan, dan penipuan. ${ }^{12}$ Sementara jika melihat dalam kasus jual beli tanah dan bangunan di atas, asas terang dan tunai tidak terpenuhi karena akta yang dibacakan Notaris EJ menyatakan dibayar tunai, namun faktanya uang pembayaran tidak diterima oleh penjual pada saat akta dibacakan oleh notaris EJ, sehingga perjanjian yang demikian seharusnya tidak dapat jalankan karena tidak syarat terang apa yang diperjanjikan oleh masing-masing pihak tidak terpenuhi. Perjanjian demikian seharusnya tidak boleh dilanjutkan karena melanggar hukum atau kesusilaan. ${ }^{13}$

\footnotetext{
${ }^{12}$ R. Subekti, Hukum Perjanjian, Cetaan Kesembilan Belas, (Jakarta: Intermasa, 2002), hal. 1.

${ }^{13}$ Ibid.
} 


\section{Jurnal Huknm Adigamä}

Volume 2 Nomor 2, Desember 2019

E-ISSN : 2655-7347

\section{B. Tanggung jawab Notaris/PPAT Dalam Pembuatan Akta Jual Beli Tanah yang Tidak Memenuhi Asas Terang dan Tunai Dalam Kasus Putusan Majelis Pengawas Pusat Notaris Nomor: 04/B/MPPN/VIII/2016}

Setiap tindakan tidak terlepas dari tanggungjawab, baik tindakan atas nama pribadi, profesi atau jabatan yang melekat padanya. Tanggungjawab sendiri timbul karena adanya hubungan kausalitas antara pihak yang mempercayakan untuk menjalankan tugas dan fungsi yang menjadi kewenangannya atau mendapatkan amanah untuk menjalankan sesuatu yang dijalankan berdasarkan profesi tertentu untuk kepentingan pihak yang memberikan tugas atau amanat. Jika pekerjaan yang dijalankan dengan baik dan sesuai dengan koridor hukum yang berlaku dan tidak menimbulkan perselisihan, maka dapat dikatakan tindakan tersebut telah memenuhi tugas yang menjadi tanggungjawabnya. Sebaliknya apabila tindakan yang dilakukan tidak memenuhi ekspektasi pihak pemberi amanat karena dalam menjalankan tugasnya melanggar ketentuan hukum yang berlaku sehingga menimbulkan resiko ketidakpastian hukum dan potensi terjadinya perselisihan.

Seseorang yang menjalankan tugas pada bidang profesi tertentu harus bisa bertanggungjawab secara profesional terhadap profesi yang disandangnya. Demikian pula profesi Notaris/PPAT sebagai pejabat umum yang berwenang membuat akta otentik, bertanggungjawab secara profesional terhadap akta yang dibuatnya jika akta tersebut di kemudian hari dipermasalahkan oleh para pihak yang terkait. Oleh karena itu, dalam menjalankan tugas profesinya, Notaris/PPAT harus memiliki integritas moral yang tinggi dalam artian dalam melaksanakan segala tugasnya harus berlandaskan pada moral dan menghindari segala sesuatu yang bertentangan meskipun akan memperoleh atau dijanjikan dengan imbalan jasa yang tinggi.

Tanggungjawab profesi Notaris/PPAT timbul karena adanya hubungan sebab akibat atas tindakan menjalankan profesi jabatan yang menjadi kewajiban dan kewenangan yang diberikan kepadanya. Hubungan antara masyarakat dengan Notaris/PPAT dalam kehidupan modern saat ini di mana dalam setiap transaksi tidak mungkin dihindarkan peran Notaris/PPAT karena sebagai pejabat yang 


\section{Jurnal HuGum Adigamä}

Volume 2 Nomor 2, Desember 2019

E-ISSN : 2655-7347

diangkat oleh pemerintah tidak semata-mata untuk kepentingan Notaris/PPAT sendiri, melainkan untuk melayani kepentingan masyarakat secara luas, ${ }^{14}$ terutama yang berhubungan dengan masalah keperdataan.

Negara melalui ketentuan peraturan perundang-undangan telah memberi kepercayaan kepada Notaris/PPAT melalui ikrar sumpah jabatan yang berarti bersedia mengemban tugas dan amanat sesuai dengan tugas dan kewenangannya dan telah siap memikul tanggungjawab atas pekerjaan yang diembannya. Tanggungjawab tersebut dapat berupa tanggungjawab hukum maupun moral. ${ }^{15}$

Tanggungjawab hukum dalam pembuatan akta menuntut bertindak sesuai ketentuan normatif yang berlaku agar dalam menjalankan profesinya selalu terkontrol dengan formalitas yang telah digariskan dengan tetap merujuk pada bentuk dari akta yang dihasilkan bukan substansi atau materi dari akta karena materi akta dan tanggungjawab atas isinya berbeda di pundak para pohak yang mengadakan perjanjian. Namun, terkadang dalam suatu akta memuat konstruksikonstruksi hukum tertentu yang sebenarnya terdapat larangan untuk dilakukan di bidang hukum perjanjian. Sebagai bentuk tanggungjawab hukum notaris dalam hal ini, notaris berkewajiban untuk mengingatkan atau memberitahu kepada para pihak bahwa perbuatannya bertentangan dengan hukum yang berlaku. ${ }^{16}$ Sedangkan tanggungjawab moral, dalam menjalankan profesi dituntut agar selalu memperbaiki terhadap kekurangan yang ada agar lebih lebih adil, lebih sesuai dengan martabat manusia, dan supaya orang-orang dapat merasakan kebahagiaan. Prinsip-prinsip moral inilah yang menjadi dasar norma kritis yang harus diletakkan dalam menjalankan profesi dalam keadaan yang semestinya. ${ }^{17}$

Salah satu tugas dan tanggungjawab Notaris/PPAT adalah membuat dan menerbitkan akta otentik yang dimintakan oleh para pihak dalam menjalani hubungan keperdataan seperti halnya yang penulis dijadikan objek penelitian yaitu terkait masalah jual beli tanah dan bangunan yang tidak memenuhi syarat

\footnotetext{
${ }^{14}$ Ismantoro Dwi Yuwono, Op.Cit., hal.172.

15 Ibid.

${ }^{16}$ Ibid, hal.193

${ }^{17}$ Khabib Lutfi, Masyarakat Indonesia dan Tanggungjawab Moralitas, (Analsis, Teori dan Perspektif Perkembangan Moralitas di Masyarakat), (Jakarta: Guepedia, 2018), hal. 71.
} 


\section{Jurnal Huknm Adigamä}

Volume 2 Nomor 2, Desember 2019

E-ISSN : 2655-7347

terang dan tunai yang telah disinggung di atas bahwa ada kesepakatan yang tidak tercapai, namun Notaris/PPAT EJ tetap melanjutkan dan para pihak diminta menandatangani akta jual beli sehingga timbul gugatan oleh pihak yang dirugikan meminta pertanggungjawaban Notaris/PPAT secara hukum dan moral.

Tidak terpenuhinya kata sepakat dalam pembayaran menjadikan tidak terpenuhinya pula syarat sahnya perjanjian karena tidak dibayar tunai seketika sesuai ketentuan bunyi akta pada saat dibacakan Notaris/PPAT EJ, akibatnya timbul gugatan ke Majelis Pengawas Notaris Daerah sampai di putus akhir melalui Majelis Pengawas Pusat Notaris. Gugatan yang diajukan tidak lain untuk mendapatkan keadilan dan kepastian hukum atas salinan minuta akta AJB yang dibuat Notaris/PPAT EJ yang kemudian dimintakan oleh Hamid selaku pihak penjual, akan tetapi Notaris/PPAT EJ tidak bisa memberikan salinan minuta akta tersebut sehingga timbul kekhawatiran karena uang penjualan belum diterima padahal dalam akta yang telah dibacakan Notaris/PPAT EJ sudah dinyatakan dibayar.

Dengan tidak menyimpan salinan minuta akta AJB tersebut, maka patut diduga dalam menjalankan tugasnya tidak berdasar pada ketentuan perundangundangan dan patut diduga ada unsur kelalaian yang disengaja dengan mengabaikan ketentuan Pasal 16 huruf g UUJN. Notaris berkewajiban menyimpan dokumen akta AJB sebagai dokumen resmi bersifat otentik memerlukan pengamanan baik terhadap akta itu sendiri maupun terhadap isinya. Penyimpanan tersebut bertujuan untuk mencegah timbulnya penyalahgunaan oleh pihak lain secara tidak bertanggung jawab.

Minuta akta AJB yang tidak disimpan dengan baik yang berakibat tidak dapat diberikannya salinan minuta yang diminta klien merupakan tindakan yang menyalahi prosedur ketentuan perundang-undangan. UUJN telah mewajibkan bagi notaris untuk menyimpan minuta yang merupakan bagian yang tidak terpisahkan dari bagian protokol notaris. Meskipun UUJN tidak mengatur secara rinci dan jelas bagimana cara penyimpanan minuta akta, karena undang-undang hanya menjelaskan penyimpanan minuta akta sebagai bentuk tindakan untuk 


\section{Jurnal Huknm Adigamä}

Volume 2 Nomor 2, Desember 2019

E-ISSN : 2655-7347

melindungi akta dari kerusakan, sehingga akta yang disimpan dengan baik keotentikannya bisa terjaga sesuai bentuk aslinya.

Dalam kondisi demikian, seharusnya Notaris/PPAT EJ wajib mengetahui keberadaan fotocopy/salinan akta jual beli tersebut apabila disimpan di kantor Notaris EJ, tetapi EJ berdalil bahwa dokumen tersebut seluruhnya berada di Bank BYB. Hal tersebut menimbulkan kebingungan bagi para pihak sehingga sangat jelas dirugikan atas hal tersebut.

Berdasarkan Pasal 16 ayat (1) huruf a dan b UUJN yang menyatakan bahwa dalam menjalankan jabatannya, Notaris wajib bertindak amanah, jujur, saksama, mandiri, tidak berpihak, dan menjaga kepentingan pihak yang terkait dalam perbuatan hukum; dan notaris wajib membuat Akta dalam bentuk Minuta Akta dan menyimpannya sebagai bagian dari Protokol Notaris

Apabila dikaitkan pada kasus di atas, Notaris EJ menurut pendapat penulis, tindakan tersebut telah bertentangan dengan Pasal 16 ayat (1) huruf a, karena dalam hal ini EJ sangat jelas berpihak kepada AO Bank BYB karena AO Bank BYB memilki surat kuasa untuk memberikan sertifikat tersebut kepada AA bukan kepada Hamid. Notaris EJ terbukti tidak menjaga kepentingan para pihak yang berkepentingan dalam proses jual beli karena sangat jelas Hamid dan RR dirugikan karena belum menerima hasil penjualan dan sertifikat telah beralih kepada pihak penjual yakni AA.

Notaris EJ juga melanggar Pasal 16 ayat (1) huruf b jo Pasal 54 Ayat (1) UUJN, karena tidak mengetahui keberadaan fotocopy/minuta akta jual beli yang diminta oleh Hamid pihak penjual dan RR selaku pembeli sudah yang sepatutnya notaris EJ membuat minuta akta dalam bentuk minuta akta dan menyimpannya sebagain protokol notaris. Dengan tidak tahunya minuta akta jual beli tersebut, menunjukkan notaris/PPAT EJ telah bertindak ceroboh dan ini tentu bertentangan dengan ketentuan kode etik notaris yang dalam dalam Pasal 3 angka ke-4 yang menyatakan Notaris dan orang lain yang memangku dan menjalankan jabatan Notaris wajib: bertindak jujur, mandiri, tidak berpihak, penuh rasa tanggung jawab, berdasarkan peraturan perundang-undangan dan isi sumpah jabatan Notaris. 
Volume 2 Nomor 2, Desember 2019

E-ISSN : 2655-7347

Penjatuhan sanksi sebagai bentuk pertanggungjawaban profesi, apabila merujuk pada kesalahan atas pelanggaran Pasal 16 Ayat (1) huruf a dan b UUJN, maka mengacu pada Pasal 85 UUJN hukuman yang dapat dijatuhkan nerupa:

1. Teguran secara lisan,

2. Teguran tertentu;

3. Pemberhentian sementara;

4. Pemberhentian dengan hormat; dan

5. Pemberhentian dengan tidak hormat.

Kelima sanksi hukuman tersebut merupakan sanksi hukuman untuk mempertanggungjawabkan profesi Notaris yang melakukan pelanggaran. Tindakan Notaris/PPAT EJ berdasarkan Putusan MPPN dinyatakan hanya bersalah melanggar Pasal 16 Ayat (1) huruf (a) UUJN karena lalai dalam melaksanakan tugas dan tanggungjawabnya yang mengakibatkan kerugian pihak lain dan dalam putusan akhir MPP hanya dikenakan sanksi teguran tertulis.

Menurut penulis, putusan MPPN kurang menggali pelanggaranpelanggaran yang telah dilakukan Notaris/PPAT EJ, mengingat terdapat beberapa kesalahan-kesalahan lain yang terungkap dalam putusan misalnya pelanggaran Pasal 16 Ayat (1) huruf b dan g UUJN karena tidak menyimpan minuta akta dengan baik pada saat diminta salinan AJB tidak dapat ditunaikan dengan alasan salinan/copyan minuta akta AJB berada pada pihak bank. Padahal sudah menjadi kewajiban Notaris menjaga dan menyimpannya dengan baik untuk mencegah timbulnya penyalahgunaan oleh pihak lain secara tidak bertanggung jawab.

Dengan demikian, berdasarkan kesalahan yang dilakukan Notaris/PPAT EJ dengan merujuk pada Putusan akhrir MPPN sanksi hukum yang diberikan sebagai bentuk pertanggungjawaban Notaris/PPAT dalam membuat akta yang tidak sesuai dengan syarat terang dan tunai hanya mendapatkan hukuman teguran tertulis. Sanksi hukuman tertulis sebagai bentuk pertanggungjawaban secara hukum menurut pandangan penulis terlalu ringan apabila melihat kerugian pihak penjual. Selain dirugikan secara materi karena tidak menerima pembayaran sesuai kesepakatan yang jelas-jelas tidak memenuhi syarat sahnya perjanjian, kerugian lain yaitu AJB yang dibuat yang tidak seusai dengan ketentuan Pasal 1320 


\section{Jurnal Huknm Adigamä}

Volume 2 Nomor 2, Desember 2019

E-ISSN : 2655-7347

KUHPer mengakibatkan akta tersebut cacat hukum yang berimplikasi akta tersebut hanya mempunyai kekuatan pembuktian sebagai akta dibawah tangan atau dapat dibatalkan (vernietigbaar), karena tidak terpenuhinya syarat subyektif yang bisa dijadikan alasan bagi pihak yang dirugikan menuntut ganti rugi kepada pihak Notaris.

Notaris/PPAT EJ dapat juga dimintakan pertanggungjawaban secara moral dalam artian tidak dapat lepas tangan begitu saja karena faktanya dalam persidangan secara hukum dinyatakan bersalah telah melakukan pelanggaran hukum yang berakibat adanya salah satu pihak yang dirugikan. Pertanggungjawaban secara moral setidaknya dilaksanakan oleh Notaris/PPAT EJ dengan cara menyatakan permintaan maaf kepada pihak yang dirugikan dan bila perlu memperbaiki akta jual beli kembali dengan cara membuat akad baru dengan tetap mengacu pada ketentuan hukum yang berlaku sehingga terciptanya keadilan dan kepastian hukum bagi para pihak sehingga tercipta kondisi masyarakat yang damai dan tenang.

Berkaitan dengan tanggung jawab Notaris EJ yang juga merangkap sebagai PPAT terhadap AJB yang merugikan salah satu pihak, maka perlu melihat terlebih dahulu kriteria perbuatannya. Untuk mengetahui hal tersebut perlu melihat unsur-unsurnya apakah dilakukan secara sengaja (dengan penuh kesadaran dan keinsyafan serta direncanakan oleh Notaris/PPAT yang bersangkutan) bahwa akta yang dibuatnya sengaja untuk secara bersama-sama dengan para pihak yang bersangkutan melakukan suatu tindakan hukum yang diketahuinya sebagai tindakan yang melanggar hukum.

Apabila melihat pelanggaran yang dilakukuan Notaris/PPAT EJ sebagaimana yang telah diuraikan di atas, di antaranya yaitu:

1. Adanya ketidaksepakatan harga terhadap AJB yang dibuat oleh Notaris/PPAT EJ karena tidak sesuai dengan harga transaksi sebenarnya yang disepakati sejak awal oleh kedua pelah pihak sehingga tidak terpenuhinya Pasal 1320 perihal syarat sahnya perjanjian.

2. Pasal 53 Ayat (2) Perka BPN 1/2006 jo No.23/2009 tentang Ketentuan Pelaksanaan PP No.37/1998 tentang Peraturan Jabatan PPAT dijelaskan 


\section{Jurnal Huknm Adigamä}

Volume 2 Nomor 2, Desember 2019

E-ISSN : 2655-7347

bahwa untuk pembuatan akta PPAT harus dilakukan berdasarkan dengan kejadian, status dan data yang benar beserta didukung data yang benar sesuai hukum yang berlaku.

3. Kode etik PPAT terdapat aturan larangan dan kewajiban PPAT dalam menjalankan tugas profesinya harus menjalankan pekerjaannya dengan penuh rasa tanggungjawab, mandiri dan tidak boleh memihak. ${ }^{18}$

Berdasarkan pelanggaran-pelanggaran tersebut, maka pembuatan AJB yang tidak sesuai dengan kesepakatan awal terhadap harga penjualan sebidang tanah dan bangunan milik $\mathrm{H}$ yang dibeli oleh AA, telah melanggar ketentuan Pasal 1320 KUHPer, Pasal 52 Ayat (2) Perka BPN 1/2006 jo No.23/2009 dan Kode Etik PPAT karena ketentuan bunyi akta AJB yang di bacakan oleh Notaris/PPAT EJ tidak sesuai dengan data yang benar. Oleh karena itu, berdasarkan Pasal 55 Perka BPN 1/2006 jo No.23/2009, PPAT dapat dimintakan pertanggungjawaban personal atas profesi tugas yang telah dijalankan dalam pembuatan akta AJB tersebut. Hukuman yang dapat diterima merujuk Pasal 28 Perka BPN 1/2006 jo No.23/2009. Berdasarkan Perka BPN tersebut, pernyataan yang tidak benar dalam akta dikategorikan sebagai pelanggaran berat yang dapat dikenakan sanksi pemberhentian dengan tidak menghargai dari perjanjiannya oleh Kepala BPN. ${ }^{19}$

Sanksi yang dapat dikenakan bagi yang melanggar Kode Etik PPAT merujuk pada Pasal 6 Ayat (1) yaitu sanksi peringatan, sanksi schorshing atau pemecatan sementara dari keanggotaan IPPAT, pemecatan dari Asosiasi IPPAT dan sanksi diberhentikan dengan tidak hormat dari keanggotaan IPPAT. Sanksi hukuman tersebut tetap disesuaikan dengan kualitas tindakan yang dilakukan sebagaimana diatur Pasal 6 Ayat (2) Kode Etik PPAT.

Dengan demikian, sanksi yang dapat diterapkan sebagai bentuk tanggungjawab bagi Notaris/PPAT EJ apabila tugas yang dijalankan sebagai PPAT yang membuat akta AJB yang tidak sesuai dengan kesepakatan harga perjanjian jual beli awal yang disepakati kedua belah pihak, maka dapat dikenakan sanksi pemberhentian dengan tidak menghargai jabatannya. Akan tetapi, dalam

\footnotetext{
${ }^{18}$ Pasal 3 Huruf e Kode Etik PPAT.

19 Pasal 28
} 


\section{Jurnal Huknm Adigamă}

Volume 2 Nomor 2, Desember 2019

E-ISSN : 2655-7347

perkara ini Notaris/PPAT EJ dilaporkan ke Majelis Pengawas Notaris sehingga kasusnya ditangani dan diputus berdasarkan ketentuan dalam UUJN dan Kode Etik Notaris.

\section{PENUTUP}

\section{A. Kesimpulan}

Dalam perjanjian jual beli tanah dan bangunan, Notaris/PPAT EJ tidak membuat AJB sesuai dengan perjanjian awal mengenai kesepakatan harga (Pasal 1320 KUHPer) yang berakibat tidak terpenuhinya asas terang dan tunai (Pasal 1457 dan 1458 KUHPer) serta melanggar Pasal 16 Ayat (1) huruf a dan b UUJN karena lalai dalam melaksanakan tugas dan tanggung-jawabnya, tidak menyimpan minuta akta yang menjadi kewajibannya sehingga Notaris/PPAT EJ dapat dikenakan sanksi sebagai bentuk pertanggungjawaban secara hukum dengan merujuk pada putusan akhir MPPN yaitu teguran tertulis. Selain itu, EJ dapat dikenakan sanksi moral berupa permintaan maaf kepada pihak yang dirugikan dan memperbaiki akta jual beli kembali dengan cara membuat akad baru dengan tetap mengacu pada ketentuan hukum yang berlaku. Apabila tugas yang dijalankan sebagai PPAT yang membuat akta AJB yang tidak sesuai dengan kesepakatan harga perjanjian jual beli awal yang disepakati kedua belah pihak, maka dapat dikenakan sanksi pemberhentian dengan tidak menghargai jabatannya.

\section{B. Saran}

Hendaknya dalam menjalankan profesi sebagai Notaris/PPAT dalam pembuatan akta tetap memperhatikan koridor hukum yang berlaku agar kepentingan para pihak tidak dirugikan dan bermasalah sehingga tercipta kondisi masyarakat yang damai dan tenang.

Bagi masyarakat yang hendak membuat suatu akta otentik yang berkaitan dengan jual beli tanah dan bangunan yang dilakukan dengan Akta Jual Beli (AJB) yang dibuat oleh Notaris/PPAT, sebaiknya memperhatikan dengan cermat syaratsyaratnya, misal dalam perjanjian jual beli perlu menegaskan kesepakatan sistem 


\section{Jurnal Huknm Adigamä}

Volume 2 Nomor 2, Desember 2019

E-ISSN : 2655-7347
Charles Delon Tunas \& Endang Pandamdari

Tanggungjawab Notaris/PPAT Dalam Pembuatan Akta Jual Beli Tanah Yang Tidak Memenuhi Asas Terang dan Tunai Dalam Kasus Putusan Majelis Pengawas Pusat Notaris Nomor: 04/B/MPPN/VIII/2016

pembayaran melalui tunai atau transfer sehingga pada saat pembuatan atau pembacaan akta AJB oleh Notaris/PPAT tidak terjadi perselisihan.

\section{DAFTAR PUSTAKA}

\section{A. Buku}

Adjie, Habib. Hukum Notaris Indonesia Tafsir Tematik Terhadap UU No. 30 Tahun 2004 Tentang Jabatan Notaris. (Bandung: Refika Aditama, 2015.)

Lutfi, Khabib. Masyarakat Indonesia dan Tanggungjawab Moralitas, (Analsis, Teori dan Perspektif Perkembangan Moralitas di Masyarakat). (Jakarta: Guepedia, 2018.)

Pengurus Ikatan Notaris Indonesia, Anke Dwi Saputro (ed), 100 Tahun Ikatan Notaris Indonesia, Jati Diri Notaris Indonesia: Dulu, Sekarang dan di Masa Mendatang. (Jakarta: Gramedia Pustaka, 2009.)

Sjaifurrachman dan Habib Adjie, Aspek Pertanggungjawaban Notaris dalam Pembuatan Akta. (Bandung: Mandar Maju, 2011).

Subekti, R. Hukum Perjanjian. Cetaan Kesembilan Belas. (Jakarta: Intermasa, 2002).

Tobing, Lumban. Peraturan Jabatan Notaris, Cetakan ke-4. (Jakarta: Erlangga, 1996).

Yuwono, Ismantoro Dwi. Memahami Berbagai Etika Profesi dan Pekerjaan. (Yogyakarta: Pustaka Yustisia, 2013.)

\section{B. Peraturan Perundang-Undang}

Undang-Undang Dasar Negara Republik Indonesia Tahun 1945.

Kitab Undang-Undang Hukum Perdata.

Undang-Undang No. 2 Tahun 2014 Tentang Perubahan Atas Undang Undang Nomor

30 Tahun 2004 tentang Jabatan Notaris; (Lembaran Negara Republik Indonesia Tahun 2014 Nomor 3; Tambahan Lembaran Negara Republik Indonesia Nomor 5491).

Peraturan Pemerintah Nomor 24 Tahun 2016 tentang Perubahan atas

Peraturan Pemerintah Nomor 37 Tahun 1998 tentang Peraturan Jabatan

Pejabat Pembuat Akta Tanah. 

Akta Jual Beli Tanah Yang Tidak Memenuhi Asas Terang dan Tunai

Volume 2 Nomor 2, Desember 2019

E-ISSN : 2655-7347

. Kode Etik Profesi Pejabat Pembuat Akta Tanah (PPAT).

Salinan Putusan Nomor 04/B/MPPN/VIII/2016.

C. Jurnal

Pomantow, Vivin. “Akibat Hukum Terhadap Akta Otentik Yang Cacat Formil Berdasarkan Pasal 1869 KUHPerdata", Jurnal Lex Privatum Vol. VI/No. 7/Sept/2018, hal.90 (90-98) 